\title{
EDITOR'S TABLE OF CONTENTS TO AMERICA AND THE AMERICANS
}

Preface

Volume I

Chapter I

Arrival in New York $\quad 7$

Chapter II The General Appearance of New York 13

Chapter III Firemen in New York 19

Chapter IV May Day in New York 23

Chapter V Domestic Manners of the Americans 28

Chapter VI American Fashions 33

Chapter VII The American Theatre 37

Chapter VIII Amusements of the Americans 40

Chapter IX American Marriages 43

Chapter X Violence in America 47

Chapter XI Education in America 53

Chapter XII American Patriotism 57

Chapter XIII American Policy towards the Indians 63

Chapter XIV The Classes in America 68

$\begin{array}{ll}\text { Chapter XV Slavery } & 73\end{array}$

$\begin{array}{ll}\text { Chapter XVI Slavery (continued) } & 79\end{array}$

Volume II

Chapter I

Drunkenness in New York $\quad 85$

\begin{tabular}{ll} 
Chapter II & Courtship in America \\
\hline
\end{tabular}

Chapter III The American Climate 91

Chapter IV American Doctors 97

Chapter V American Produce 100

Chapter VI The American Character 105

Chapter VII American Government 113

Chapter VIII The Electoral System 117

Chapter IX Church and State in America 125

Chapter X Sunday in New York 140

Chapter XI The American Legal System 142

Chapter XII Employment in America 147

Chapter XIII Employment in America (continued) 150

Chapter XIV American Poverty 152

Chapter XV American Poverty (continued) 155

Chapter XVI The Miseries of Emigration 157

Chapter XVII The Miseries of Emigration (continued) 162

Chapter XVIII American Packets 167 